\title{
Eugeniusz Wilk, Iwona Kolasińska-Pasterczyk (red.). 2008. Nowa audiowizualność - nowy paradygmat kultury?. Kraków: Wydawnictwo Uniwersytetu Jagiellońskiego, ss. 424
}

W alter Benjamin w latach 30. XX wieku, przede wszystkim w Pasażach, choć nie tylko tam, dokonał antycypacyjnego opisu kultury współczesnej, a Adorno i Horkheimer w pisanej w czasie drugiej wojny światowej Dialektyce oświecenia (zob. esej pt. Przemysł kulturalny) przedstawili świat, który dzięki nowym mediom czy - jak chcą autorzy recenzowanej antologii - nowej audiowizualności staje się w coraz większym stopniu naszym udziałem. I choć przywołane nazwiska pojawiają się w tekstach zamieszczonych w tomie rzadko, to jednak wydaje się, że są one (nie zawsze w pełni świadomie) punktem odniesienia dla wielu spośród nich. I nie dzieje się tak dlatego, że ich autorzy wieszczą apokaliptyczną wizję końca kultury, ale dlatego, że stają oni wobec dylematów i pytań, które przywołani tu myśliciele formułowali ponad pół wieku temu. Choć ich odpowiedzi nie mogą być z perspektywy XXI wieku zadowalające, to problemy i diagnozy nic nie straciły ze swej aktualności.

Zaproponowane przez badaczy spojrzenia oferują czytelnikowi szerokie spektrum zarówno tematyczne, jak i metodologiczne, od ujęć teoretycznych (przede wszystkim w części l, ale także III) po analizy konkretnych realizacji nowych audiowizualnych rozwiązań (zwłaszcza w ostatnim fragmencie). W poszczególnych tekstach widoczne są wpływy hermeneutyki Gadamera, strukturalizmu, jak również postmodernistycznych metodologii spod znaku Derridy i Foucaulta. Taki punkt wyjścia pozwala nie bez satysfakcji przyglądać się zmaganiom badaczy z tym, co najnowsze, a więc w opisie najtrudniejsze, a w definiowaniu najbardziej niebezpieczne.

Kompozycja niniejszej wypowiedzi będzie odwzorowywać podział zaproponowany przez redaktorów tomu. Swoje uwagi autor recenzji odniesie do czterech kolejnych części zbioru, które tworzą w jego ramach mniejsze, ale w dużym stopniu samodzielne segmenty. 


\section{Część I - Kultura audiowizualna}

Ta część zbioru ma charakter antropologiczno-filozoficznej refleksji nad zdefiniowaną $w$ tytule nową wizją kultury. Tom otwiera świetny pod względem metodologicznym artykułWojciecha J. Burszty O trzech pojęciach metakultury. Bez wątpienia tekst ten zasługuje na miano „lektury obowiązkowej" dla studentów kulturoznawstwa, ale również dla tych, których pole zainteresowań obejmuje funkcjonowanie w symbolicznym świecie kultury współczesnej (właśnie wciąż jednak symbolicznym, a nie symulakrycznym, jak próbuje dowodzić Baudrillard).

Na uwagę zasługują refleksje Eugeniusza Wilka i Waldemara Frąca wywodzące się z namysłu nad filozofią Martina Heideggera. Obaj badacze nawiązują do późnego okresu twórczości niemieckiego filozofa, widząc w nim tego, który pyta o techniczną i etyczną stronę mediów i dostrzega w nich zagrożenia dla człowieka. Właśnie w tekstach Wilka i Frąca refleksje autorów Dialektyki oświecenia są jak najbardziej uprawomocnionym kontekstem ideowym, a nawet politycznym (czego w wypadku Heideggera uniknąć się nie da).

Artykuły Piotra Zawojskiego oraz Konrada Chmieleckiego zawierają teoretyczną perspektywę, co jest sygnalizowane już w podtytułach. Oba wystąpienia stanowią odważne wyjście ku próbom zdefiniowania zjawisk związanych z nowymi mediami. Mimo różnicy w podejściu (paradygmatyczność a perspektywa semiotyczna) badacze dążą do podobnego celu, to jest wyznaczenia pól badawczych i pojęciowych dla opisu gwałtownie zmieniającego się świata (w tekście Zawojskiego dziesięć lat istnienia cyberkultury rozpada się na trzy podokresy).

Artykuły Blanki Brzozowskiej, Anny Maj oraz Kariny Banaszkiewicz-Sadowskiej łączy tematyka podróży, autorki zastanawiają się, jakie konsekwencje dla naszego postrzegania świata rodzi przemieszczanie się. Kategoria turysty i podróżnika opisywana przez badaczki znacząco kieruje uwagę na nomadę, człowieka mediów elektronicznych scharakteryzowanego niegdyś przez McLuhana [2004: 13 i n.]. Kontekst ten wart jest pogłębionej refleksji, gdyż wskazuje na nowy wręcz paradygmat człowieka (podczas gdy w przywołanych tekstach mówi się jedynie o nowym typie człowieka).

Interesujące wnioski wypływają również z wypowiedzi Janiny Hajduk-Nijakowskiej, która - dostrzegając w ramach globalnej kultury nowe pola badawcze dla etnologów - przekonuje, że zjawisko pogłoski czy plotki można badać takimi samymi narzędziami, jakie stosuje się w przypadku małych kultur, uwzględniając oczywiście zwielokrotnioną nośność przekazu.

\section{Część II - W stronę sztuki}

Pięć tekstów zamieszczonych w tej części tomu daje szeroki przegląd przemian $w$ tworzeniu, przekazie i rozumieniu sztuki, z jakimi mamy do czynienia na prze- 
strzeni minionego wieku. W centrum rozstrzelonych tematycznie rozważań znajduje się tekst Ryszarda W. Kluszczyńskiego, który przedstawia rzetelny i poręczny przegląd form i historii sztuki interaktywnej. Zwraca on uwagę na partycypacyjność kultury najnowszej, w której ramach podział na twórcę i odbiorcę staje się coraz bardziej problematyczny, ostatecznie bowiem odbiorca może kształtować finalny obraz dzieła w sposób przez twórcę niezakładany. Agata Bielik-Robson [2008] przedstawiała ów stan jako marzenie romantycznych antenatów, dążących do nieustannego poszukiwania możliwości powrotu do siebie w nowej formule.

Wokół tego centralnego punktu interesująco rozwijają się rozważania Andrzeja Gwoździa o roli celuloidu jako swoistego motywu w kinie, wypowiedź Małgorzaty Szelmowskiej o przemianach związanych z pojawieniem się sztuki wideo oraz Andrzeja Kisielewskiego refleksje nad estetyką populizmu.

Kontrapunktem dla tego myślowo zwartego bloku okazuje się tekst Tomasza Majewskiego dotyczący ikonografii histerii i działalności Jeana Martina Charcota. Można go potraktować w kategoriach Foucaultowskiej archeologii i odczytać jako swego rodzaju zapowiedź, XIX-wieczną antycypację sztuki współczesnej - z jej grą między autentycznością a udawaniem, cierpieniem i ekshibicjonizmem, z czym tak często mamy do czynienia we współczesnych mediach. Należy wyrazić żal, że redaktorzy nie zamieścili choćby kilku reprodukcji zdjęć Charcotowych histeryczek, wraz z komentarzem badacza stanowiłyby one dodatkową wartość tomu.

\section{Część III - Nowe media}

Ta część zbioru wprowadza wątki, na które warto zwrócić uwagę, gdyż - choć rzadko werbalizowane - stanowią istotne tło rozważań badaczy.

Nowe media tworzą własny świat i jednocześnie domagają się nowego języka dla ich opisania. W związku z tym badacze zwykle zaczynają swe wypowiedzi od definiowania pojęć, którymi zamierzają się posługiwać. Powstaje z tego lingua franca XXI wieku; łatwo się zagubić na jej obszarze, nie tylko ze względu na zapożyczanie pojęć z języka angielskiego i posiłkowanie się neologizmami. Odrębnym problemem jest dynamika tego języka: pojęcia wprowadzane przed zaledwie dziesięcioma laty okazują się już nieadekwatne i wymagają redefinicji. Mamy tu do czynienia $z$ efektem ubocznym gwałtownego rozwoju nowych mediów (szczególnie Internetu), za którym naukowy opis nie zawsze nadąża, nie zwalnia to jednak medioznawców i przedstawicieli innych dyscyplin z obowiązku podejmowania refleksji i choćby próby syntezy.

Gdybyśmy użyli metafory „spotkania z Innym", tak bardzo rozpowszechnionej we współczesnej filozofii, a następnie - upraszczając - za Innego uznali nowe media, to może się okazać, że nasz wysiłek badawczy w pewnym sensie zawsze skazany będzie na niepowodzenie. Choć musimy go ciągle na nowo podejmo- 
wać, w gruncie rzeczy ten Inny zawsze będzie się nam wymykał, nigdy go w pełni nie zrozumiemy, do czego - zdaniem Waldemara Kuligowskiego [1998: 23] - przyznaje się Lévi-Strauss w Smutku tropików, pisząc o stosunku do Indian. Podobni do Syzyfa (w interpretacji Alberta Camusa), nie możemy zaprzestać naszych wysiłków, a jednocześnie nieodmiennie jesteśmy świadomi ich bezcelowości.

Obok języka opisu istotnym problemem badaczy zmagających się z fenomenem nowych mediów tudzież konsekwencjami ich oddziaływania jest metodologia. Autorzy (np. Monika Górska-Olesińska) podkreślają, że dyskurs naukowy jest obecnie zdominowany przez poststrukturalizm, z Derridą, Barthesem i Foucaultem na czele. Co prawda, zwłaszcza dwaj pierwsi myśliciele często z mediami „romansowali”, można jednak zadać pytanie, czy nie należałoby sformułować konstruktów metodologicznych nieodwołujących się do świata niezwirtualizowanego. Ukazując klęskę projektu wirtualizacji rzeczywistości, uwagę na ten problem zwraca Grzegorz Dziamski, chociaż nie czyni tego wprost.

\section{Część IV - Kino i telewizja}

Ostatnią część tomu stanowią przede wszystkim analizy twórczości filmowej (z wyjątkiem tekstu Zbigniewa W. Solskiego, który dokonał pogłębionej analizy Do piachu Różewicza w realizacji telewizyjnej, oraz interesującego studium Alicji Kisielewskiej na temat społeczno- i kulturotwórczej roli seriali). Mimo zastosowania bardzo różnych kluczy interpretacyjnych (biograficznego, intertekstualnego, historycznego, semiotycznego czy wreszcie antropologicznego) wszystkie głosy zbiegły się w zgodny chór podejmujący kwestie tożsamości, pamięci i doświadczenia. Nic w tym dziwnego, wszak kategorie te stały się w ostatnich latach wiodące w refleksji humanistycznej. Należy zwrócić uwagę zwłaszcza na dwie ostatnie, splecione nie tylko dyskursem psychoanalitycznym. Pamięć i doświadczenie stały się także odpowiedzią na okrucieństwo XX wieku; ten wątek został szczególnie wyeksponowany w tekście Krzysztofa Loski, który zainteresował się filmową recepcją traumy po tureckiej rzezi Ormian, a także w pracy Rafała Syski o austriackich demonach nazizmu, jakie wydobywa w swych filmach Michael Haneke.

Oczywiście, w żadnym z prezentowanych tekstów pojęcia te nie są analizowane samoistnie, za każdym razem konstytuuje je tekst dzieła filmowego i rozpoznawany przez badacza trop czy ślad - w sensie zaproponowanym przez Paula Ricoeura [2007: 59]. I choć żaden z autorów nie powołał się wprost na tego filozofa, myśl wielkiego hermeneuty jest immanentnie obecna w ich refleksji. Szczególnie uzmysławia to praca Beaty Lisowskiej, która przeanalizowała relacje ojca i syna w filmie Powrót Andrieja Zwiagincewa. Mamy dowód w postaci antropologicznego nachylenia, którego badaczka nie ukrywa, jak i samą materię filmu, będącą doświadczeniem rytuału przejścia pozostawiającego trwały (w filmie tragiczny) ślad w bohaterach. 
Nie można pominąć wątku intertekstualnego, który w kulturze postmodernistycznej zdobył rangę wiodącą, wszak "wszystko już było". Pojawia się on w kilku tekstach i na różne sposoby bywa wykorzystywany. Prześmiewczy ton pobrzmiewa w artykule Grażyny Stachówny o parodiach reklam w filmach Pedra Almodóvara. Badaczka wyeksponowała tak charakterystyczny dla hiszpańskiego reżysera, niemal bluźnierczy motyw gry ze świętością w reklamie proszku Ecce Omo. Z kolei Iwona Kolasińska-Pasterczyk rozpoznaje gry wielomedialne w twórczości Davida Lyncha, a Joanna Opalińska-Mazur dostrzega związki między filmami Murnaua i braci Wachowskich.

Ostatnia część omawianego tu zbioru wydaje się najbardziej spójna. Osadzone w kulturowym kontekście oglądy wybranych dzieł filmowych ukazują w czytelny sposób zmaganie się z pytaniem o nowy paradygmat kultury. Odpowiedzi, jakich udziela się na tę kwestię w całym tomie, nie są jednoznaczne, niemniej z całą pewnością rejestrują drgnienia i rewolucje wywołane gwałtowną zmianą technologiczną w obrębie audiowizualności, z czym mamy do czynienia w kulturze w ciągu ostatnich dekad. Jak każda tego typu publikacja, Nowa audiowizualność - nowy paradygmat kultury? to dzieło nierówne pod względem poziomu merytorycznego. Nie ulega jednak wątpliwości, że zamieszczone tu artykuły łącznie stanowią interesującą panoramę: najnowszych zjawisk i ich interpretacji w obszarze mediów z jednej strony, z drugiej zaś - zainteresowań badaczy i stosowanych przez nich metodologii, co samo w sobie również stanowi wartość.

\section{Bibliografia}

Bielik-Robson Agata. 2008. Duch powierzchni. Rewizja romantyczna i filozoficzna. Kraków: Universitas.

Kuligowski Waldemar. 1998. Teoria: podróż ku przekroczeniu. [w:] J. Topolski (red.). Interpretacja jako konstrukcja. Poznań: Instytut Historii UAM.

McLuhan Marshall. 2004. Zrozumieć media: przedłużenia człowieka. Warszawa: Wydawnictwo Naukowo-Techniczne.

Ricoeur Paul. 2007. Pamięć, historia, zapomnienie. Kraków: Universitas.

Mirosław Gołuński

(Uniwersytet Kazimierza Wielkiego w Bydgoszczy) 